\title{
To Remember or Not To Remember: Questioning Trauma of Slavery in Beloved
}

\author{
Shahram R. Sistani \\ Department of Foreign Languages, Bahonar University of Kerman, Iran \\ E-mail: shahramsistani@gmail.com
}

Received: 19-01-2016

Published: 01-07-2016
Accepted: 10-04-2016

doi:10.7575/aiac.ijalel.v.5n.4p.52
Advance Access Published: May 2016

URL: http://dx.doi.org/10.7575/aiac.ijalel.v.5n.4p.52

\begin{abstract}
Why do characters are not willing to remember the past? Do their quest for self-definition is prompted by different needs? To what extent the relationship of the individual to their communities matters and has an impact on their process of remembering? Almost there is no doubt in the role of history in establishing a better present or future. That's why the master ideologies have historically distorted the reality and belittling the black culture. This paper seeks to examine how In Toni Morrison's Beloved (1987) some characters are driven by a dire desire to free themselves from the painful memory of slavery and in contrast to them some others find respites and their quest for the self in coming to term with the past. The first part of the title of this study i.e. "To Remember or not to Remember" refers to the question of remembering or not to remembering and if it's necessary in characters' attempt for self-definition. For the reason that Morrison believes, "There is a necessary for remembering the horror, but of course there's a necessity for remembering it in a manner in which it can be digested, in a manner in which the memory is not destructive" (Marsha Darling 1994, 247-48). The second part that is "Questioning of Trauma of Slavery" of the title addresses the attempts of seminal characters to redeem the slavery situation by reaching to the subjectivity or coming to terms with pre-destined condition thereby making earnest attempts to discover new opportunities and alternative ways of questioning the trauma of slavery. This study attempts to provide an Althusserian - Lacanian reading of the quest of subjectivity and to conclude that resolving the trauma of the past helps characters to free their psyches from the entanglement of slavery and be able to construct a better relationship with the structure.
\end{abstract}

Keywords: trauma of the past, ideology, structure, memory

\section{Introduction}

Toni Morrison explores the fragmented psyches of the characters in her brilliant work Beloved. She examines the repression and the fragmented memories of slavery very carefully. It narrates the characters' strong predilections for finding a place to define themselves. Sethe the protagonist loses self for the reason of the painful memory of her experiences in the course of the novel. She murders her daughter Beloved to save her from the agony of slavery. The novel gives a brilliant picture of the impacts of Sethe's act on her psyche. In the course of her life, she suffers of the lack of identity and tries to reconstruct it. Beloved resurrects and suffocates Sethe's selfhood. Sethe's efforts to achieve freedom from the hands of slave master ideology of the society from one side and from Beloved in the other side can be studied in the light of psycho-social investigations of Louis Althusser and Jacques Lacan. The story is given to us in the form of flash backs. But it is not similar to other slave narratives in the sense that it does not give a mere depiction of some tough events that blacks experienced and come out of them as heroic journey. Morrison focuses more on the race and their traumatized self-annihilations. By this way she reconstructs and redefine the history of slavery. As the society and the outdoor life becomes more savage and brutal for subjects, Morrison seeks a haven in family life. All members of the family are subject to a contaminated atmosphere. Parents are denied even their own children at the whim of white masters. Women are exchanged as valuable objects. They are not allowed to have cordial relationship with their family members.

Morrison focuses mostly on mother-daughter relationship. The situation that drives Sethe to commit the infanticide is a crucial point not only in the life of her but also in the course of the novel. Sethe is haunted by the ghost of Beloved that is an important element in losing her freedom and selfhood. As Bernard Bell remarks:

On a sociopsychological level, Beloved is the story of Sethe Suggs's quest for social freedom and psychological wholeness. Sethe struggles with the haunting memory of her slave past and the retribution of Beloved, the ghost of the infant daughter that she killed in order to save her from the living death of slavery. On a legendary and mythic level, Beloved is a ghost story that frames embedded narratives of the impact of slavery, racism, and sexism on the capacity for love, faith, and community of black families, especially of black women, during the Reconstruction period. (1992, 89) 
The novel depicts a period around 1860s to 1870 s which is a crucial point in the history of the United States and in the memory of black people. Demetrakopoulos utters that this novel of Morrison, "thematizes and problematizes the conflict between history, culture and maternal instincts" $(1992,15)$. The role of mother is scrutinized in a delicate way to show the reasons behind disintegration of black identity in a new panorama. Under the slave master's ideology, slave women were denied their rights to upbringing their children. Their babies were taken from them as commodities. In the novel, Sethe also is taken from her mother. As Paul D. a major character in the novel believes, loving children was a hazardous and fiendish act. This is against the law of reason and creates anxiety a fact which Erich Fromm believes,

The experience of separateness arouses anxiety; it is, indeed, the source of all anxiety. Being separate means being cut off, without any capacity to use my human powers. Hence to be separate means to be helpless, unable to grasp the world-things and people-actively; it means that the world can invade me without my ability to react. Thus separateness is the source of intense anxiety. Beyond that, it arouses shame and and the feeling of guilt. $(1956,7)$

In the novel the role of mother is significant in forming selfhood. Mothers are, "property that produces itself without cost" (288). Sethe revolts against such an ideology. As Gurleen Grewall opines Sethe, "incurs the rancor and resentment of the women in the community because of her extreme refusal to define herself a breeder of slaves" (1994, 156). For this reason characters generally are not willing to remember their painful past but these memories return and hunts the present selves. Morrison also substantiate this point in an interview with Angelo Bonnie,

I thought this is (sic) got to be the least read of all the books I'd written because it is about something that the characters don't want to remember, black people don't want to remember, white people don't want to remember. I mean it's national amnesia. $(1989,120)$

Sethe's unwillingness and disinterestedness in future and in construction a selfhood are depicted in these lines of the text.

Why was there nothing it refused? No misery, no regret, no hateful picture too rotten to accept? Like a greedy child it snatched up everything. Just one, could it say, No thank you? I just ate and can't hold another bite? I am full God damn it of two boys with mossy teeth, one sucking on my breast the other holding me down, their book-reading teacher watching and writing it up.(70)

In Beloved, the life of the blacks and their working condition is actually an epitome of their suffrage under slavery. Their plantation is called ironically Sweet Home. Sethe and most of the workers are deceived that this is the best place for them. After quite sometimes, they understand that the farm is a hell. As a matter of fact, what Mr. Garner plants in the slaves' psyche is an illusory percept of selfhood. The situation even becomes worse after death of Mr. Garner and when the responsibility is assigned to the Schoolteacher. His malicious treatment of slaves prompts them to plan a scape in search of freedom. Such a treatment ingrains an inferiority complex. Sethe suffers a lot in the hands of the Schoolteacher. He is the symbol of a brutal master. Sethe says,

Schoolteacher was teaching us things we couldn't learn. I didn't care nothing about the measuring string. We all laughed about that-- except Sixo. He didn't laugh at nothing. But I didn't care. Schoolteacher's wrap that string all over my head, 'cross my nose, around my behind. Number my teeth. I thought he was a fool. And the questions he asked was the biggest foolishness of all. (191)

She feels suffocated in that atmosphere for the reason that Schoolteacher abuses her humanity. Hilda Bernstein avers,

the women have the burden doubled: the black consciousness of' "inferiority" ingrained by the colonists, the destruction of tribal structures that gave status to both sexes and (he denigration of any culture other than that of the colonists themselves is the first imposition: the second is the inferior status imposed by the relationship of the men and women. (Kolawole 1997, 29)

Her escape is a resurgence of the role of past experience and an attempt to fight with the structure for self-definition. At this stage, she thinks by escaping she will be able to forget the past memories. But truth is that they cannot be forgotten because the past gets integrated into the present. It only elaborates her desire to free her children from mental and emotional traumas of slavery.

No notebook for my babies and no measuring string neither. What I had to get through later I got through because of you. Passed right by those boys hanging in the trees. One had Paul A's shirt on but not his feet or his head. I walked right on by because only me had your milk, and God do what He would, I was going to get it to you. You remember that, don't you; that I did? That when I got here I had milk enough for all? (198) 
Murdering Beloved is also part of a struggle for selfhood, "For Sethe ... to kill her daughter is to kill her own best and self-gendered fantasy of the future. The act is like killing time itself, especially its redemptive gifts, which the daughter, as a potential mother, symbolizes" (53). In her search for selfhood, she thinks that her being is thwarted and abused by the slavery. Even Schoolteacher's nephews are doing under the command of him in harassing Sethe. She tells Paul D about one occasion when she was pregnant,

After I left you, those boys came in there and took my milk. That's what they came in for. Held me down and took it. I told Mrs. Garner on em. She had that lump and couldn't speak but her eyes rolled out tears. Them boys found out I told on em. Schoolteacher made me open up my back, and when it closed it made me a tree. It grows there still. (16-17)

As a whole, the novel is a quest for freedom and subjectivity. Psychoanalytic investigations of Althusser and Lacan give us an opportunity to interrogate the structure of Sethe's thinking behind her struggle in surface level, and in this sense Morrison's work is more properly philosophical and psychological than that of those who investigated from historical view point. The story of Beloved is the story of United States. It is the story of collective slaves. Because the unconscious is present in it and reminds the Lacan's statement, "Unconscious is discourse of the Other." Morrison's novel, gives us a free access to the voice of the unconscious. In the novel the fact of resurgence of Beloved reenacts the tenets of Althusserian and Lacanian theories. In the novel Sethe finds a newly identity by being accepted into the community and help of some friends. Sethe's life story contains repressed material that she has to come with. These materials depicts a record of the presence of Other's ideology. As Lacan believes, "Once the subject himself comes into being, he owes it to a certain nonbeing upon which he raises up his being" $(1988,192)$. In the following discussion the aim is to have an investigation of the existence of the Other in Sethe's course of life. Throughout of this study the framework is an Althusserian Lacanian reading.

\section{Discussion}

It is possible to consider the concept of ideology in the Beloved from Althusserian view point. For the reason that Beloved depicts the myths and imaginary conception of real social relationships which are influential in structure's ideology. It is through an Althusserian reading that we can distinguish the real place of the subjects and understand their images and desires. Based on this view point, subject's real relations are depicted in these parts of psyche not in the prevalent ideology. In Beloved, Sethe's real relation is rooted in her memories and stories that she inherited from her parents and also images that she herself imagined in the Sweet Home. In this farm she is totally isolated from the community. As Denver daughter of Sethe once says,

I am afraid the thing that happened that made it all right for my mother to kill my sister could happen again. I don't know what it is, but maybe there is something else terrible enough to make her do it again I need to know what that thing might be, but I don't want to. (211)

This is the ideology which has both imaginary and real aspects. The part that even Denver interacts with her community and experiences in outdoor live in her social relationship is called the real one. The imaginary one is the part that she is not able to understand the reasons behind it, discourages her about existence and places her in a specific class and is responsible for making them slaves and exists in their mind is imaginary one. Althusser utters, "But what is represented in ideology is 'not the system of the real relations which govern the existence of individuals, but the imaginary relation of those individuals to the real relations in which they live" $(1971,155)$. In his view, ideology always resides in truism and imaginary believes. Sethe's endeavor to search for selfhood is beyond her desire for freedom. She is in search of a basic right to nurture and preserve her children. When she sees children's future is at risk by slavery, she would rather to kill them in order to save them from a wretched condition. Her murdering of Beloved is not instigated by her desire for escaping from responsibility but because of the lack of mothering experience which the imaginary ideology (slavemaster) has devoid her from. Sethe's experiencing of motherhood is shaped based on her memories. Memories that are deprived of love and affections since ideology does not allow slave mothers to play their role as the source of care and affection. Schapiro substantiates the point, "Sethe was not physically starved for milk as baby - she did not receive milk from another nursing slave woman - but she was emotionally starved of a significant nurturing relationship, of which the nursing milk is symbolic" $(1991,198)$. Unfortunately, Sethe experience the same traumas as her mother. For instance, once she showed her a mark of slavery carved on her rip. Sethe also was imprinted such a sign on her back. They both were denied the loss of selfhood in different stages in life most importantly during their married lives. After being informed that for some generations they were denied the most basic signs of humanity, she is intended to change her destiny by any price. Ideology degraded the condition of her existence in the interest of the dehumanizing slavemaster structure. This ideology is constructed and preserved by not only what Althusser calls Ideological State Apparatuses but also Repressive State Apparatuses. In the novel Sethe is at first subject to ISAs. Her situation in the Sweet Home and in the plantation of Mr. Garner elaborates this idea in a clear way. It is he who deceives them about the idea of freedom. She thinks that they are free to choose the needs and ways of life. It is later that the slaves understand that all acts of him is for the benefit of dominant ideology. Mr. Garner creates a fake identity in their psyche. As a matter of fact, only when Seth escapes from plantation we come to know the cruel nature of masters.

Morrison depicts Mr. Garner as a model of ISAs and Schoolteacher as symbol of RSAs. The brutal treatment of Sethe in the hands of Schoolteacher is only for the reason of constructing her as subject. Althusser remarks, 
I say: the category of the subject is constitutive of all ideology, but at the same time and immediately I add that the category of the subject is only constitutive of all ideology insofar as all ideology has the function (which defines it) of 'constituting' concrete individuals as subjects. $(1971,160)$

In the novel the white people are depicted as autonomous subjects that have acquired subjectivity because the ideology supports their wellbeing's. In Levinas' view point, "Humanism, after all, is not merely the affirmation of the dignity of one person, of each individual alone; it is also an affirmation of the dignity of all humanity, the affirmation of an interhuman morality, community, and social justice" (Cohen, 2006, xviii). They are allowed to enter into domain of language. They acquire the "I" position in the utterance who is permitted to speak. In Lacanian analysis, there is a drastic difference between this "I" and the one who is mentioned in the utterance. There is a difference between these two I's because the latter one is only a substitute and is never permitted to play a seminal role in the utterance. Belsey opines, "It is this contradiction in the subject - between the conscious self, which is conscious in so far as it is able to feature in language, and the self which is only partially represented there-which constitutes the source of possible change" $(2001,70)$. Sethe is not authorized to signify or being considered as the "I." She expresses her resentment over some experiences several times in the course of the novel.

I am full God damn it of two boys with mossy teeth, one sucking on my breast the other holding me down, their book-reading teacher watching and writing it up. I am still full of that, God damn it, I can't go back and add more. Add my husband to it, watching, above me in the loft-hiding close bythe one place he though no one would look for him, looking down on what I couldn't look at at all. (70)

These lines show the extent to which she is subjected to other's desire. There is no place for her desire and only in the interest of the structure which propagates racism. The system promotes the idea of considering women salve as a breeder and as an object of their desire. It accords with the idea of Lacan that "Desire is desire of the Other." The schoolteacher's insistence to take back Sethe to the plantation justifies only one thing that his endeavor is aimed for giving services to the structure. "He wasn't surprised to learn that they had tracked her down in Cincinnati, because, when he thought about it now, her price was greater than his; property that reproduced itself without cost" (228). His thought shows the suppression of any desire for freedom in Sethe. Sethe's selfhood is decentered and not able to make a right decision. As a matter of fact, she does not identify with the Schoolteacher as the agent of the structure because she was intended to fight with the trauma of slavery. Her decision to escape from Schoolteacher's subjection is instigated by her desire to free her children from such a destiny. The novel is full of brilliant samples of her endeavors for passing through the trauma of slavery. These narratives bring to the light the ideological norms, ethical codes, the sense of motherhood in Sethe in stark contrast with those of structure. In her attempts to define herself she is isolated from community, and is not succeeded in promoting her ideology because the same presents her position as unchangeable. The situation is intensified because of the lack of communication between Sethe and the community. This isolation troubles her a lot as she remarks, "Freeing yourself was one thing; claiming ownership of that freed self was another" (95). Due to the trauma of slavery she cannot escape in the real sense of the word from the past memories. For the reason that those memories cannot be neglected. The past has always been part of the present and future.

Sethe's social relationship finally changes her attitude and way of enduring the tyranny of the structure. Some characters such as Amy Denver and, Baby Suggs, Paul D. facilitate her trauma of slavery and search for freedom. Amy plays a pivotal role in her construction of the self. It is in their mutual relationship that Morrison conveys a key idea. Although each belong to a different class but they succeed in making a productive relationship. Both suffered from a similar trauma. Although Amy is a white woman but she suffered from the same structure after losing his father. Both have lost their parents in one way at the beginning of their life. They are escaping from a brutal system to find a way for self-definition. Sethe spends her twenty-eight days of freedom in Suggs' house. These days help her to identify herself and incorporate herself into the community. Sethe disintegrates this precious freedom by her act of infanticide and because of the arrival of the Schoolteacher. Her act can be interpreted as a cause to system to recognize her right of motherhood. However, this is the price she paid for the trauma of remembering. She is in search of an identity for herself to save her children but in the middle of the way the act of remembering and trauma of slavery abrupt her quest. This causes her feel guilty. Here Sehte's ethical and ideological codes of motherhood, care, and love are set against the desire of the structure, which comes to the light at this point and this is beyond her tolerance. Sethe's sense of motherhood and love as a subject of this structure and ideology become a revolt to the remembering the past memories. In this course of time her sense of identity put an end to her capacity to participate constructively in the symbolic order of language and structure.

In Lacanian opinion, a subjects as enters into the realm of symbolic comes under the influence of the Law. "It is in the name of the father that we must recognize the support of the symbolic function which, from the dawn of history, has identified his person with the figure of the law" $(1977,67)$. The name of the father symbolizes the ideology and structure. So, in a racist ideology the name is symbol of the Other. It means that Sethe is establishing her identity in a way or other based on the prevalent Other. In the other word, she escapes the memories of the past to live as an independent subject under the Name of the Father. Sethe should learn that it is only through controlling our desire that we can reach to the subjectivity. The act of remembering the past that spreads throughout of the novel is a sign of the existence of the primal father and the existing ideology. It is by different speeches of Sehte that a reader can have an 
idea of illusory nature of selfhood in the structure. Characters in the novel struggle very hard to fight with the ideology. Slavoj Zizek substantiates the point by stating, such an ideology is " a kind of reality whose very ontological consistency implies a certain non-knowledge of its participants - if we come to 'know too much,' to pierce the true functioning of social reality, this reality would dissolve itself" $(1989,21)$.

Paul D. is the other character who plays a major role in Sethe's entrance into the community. Morrison gives prominence to the role community in coming to terms with the structure. S.C. Aikant believes, "through the communal interaction, the individual proceeds from repressive isolation to a developed sense of the self” (1998, 162). Paul D. assists Sethe in remembering trauma of the past. By awakening her feminine derives that she had repressed for quite a long time, Paul changes her view point to the world of communal life. He succeeds in managing the impediments. He sooths her fractured psyche by enabling her to see a world beyond the enclosed space. As a matter of fact, Paul's act accords with Levinas' idea of Humanism. In Cohen's view point, "For Levinas, the dignity of the self arises in and as unsurpassable moral responsibility to and for the other person. And moral responsibility for the one who faces leads to the demand for justice for all those who do not face, for all others, all humanity" (2006, xxvii). It is by these steps that she is able to remember the trauma of the past and come to terms with their hurdles. Both of them are in search of their selves but in a distinct way. As a whole, their psyches are a narrative of the similar experiences of the trauma of slavery.

Only this woman Sethe could have left him his manhood like that. He wants to put his story next to hers.

"Sethe," he says, "me and you, we got more yesterday than anybody. We need some kind of tomorrow."

He leans over and takes her hand. With the other he touches her face. "You your best thing, Sethe. You are." His holding fingers are holding hers. (273)

From this moment onwards Sethe and Paul are ready to remember the past to live in harmony and understand themselves better and strive to make a better and secure place in the future.

\section{Conclusion}

In Beloved the fact of remembering the past is a crucial issue in the life of major characters. For the reason that, it helps them to free their psyches from the trauma of slavery and to play a constructive role in their community. Their attempt in suppressing the memories is a useless endeavor, because it hunts their psyches each time they confront with a new experience. As a whole, it is a novel of remembering. In order to gain freedom from a troubled past, Morrison's character attempts a relocation of those terrifying experiences.

"I was talking about time. It's so hard for me to believe in it. Some things go. Pass on. Some things just stay. I used to think it was my rememory. You know. Some things you forget. Other things you never do. But it's not. Places, places are still there. If a house burns down, it's gone, but the place--the picture of it--stays, and not just in my rememory, but out there, in the world. What I remember is a picture floating around out there outside my head. I mean, even if I don't think it, even if I die, the picture of what I did, or knew, or saw is still out there. Right in the place where it happened." (p. 36)

Sethe and other characters afraid to confront with those sad memories that's why they try to forget these but finally they understand that these memories are in fact building blocks of the future. To remember is a healing touch for the wounds that characters suffered from. As Marilyn S. Mobley rightly utters Morrison,

uses memory as the metaphorical sign of the interior life to explore and represent dimensions of slave life that the classic slave narrative omitted. By so doing, she seeks to make slavery accessible to readers for whom slavery is not a memory, but a remote historical fact to be ignored, repressed or forgotten. (357-58)

The present article tries to show that in the novel it is through controlling one's desire that he or she can reach to the subjectivity. The act of remembering the past that a reader can easily recognize throughout of the novel, is a sign of the existence of the law of the father. Recognizing this law, changes Sethe's attitude and way of enduring the tyranny of the structure.

\section{Reference}

Althusser, L. (1971). Lenin and Philosophy and Other Essays, Trans. Ben Brewster, London: New Left Books.

Angelo, B. (1994). The Pain of Being Black: An Interview with Toni Morrison. Conversations with Toni Morrison. Ed. Danille Taylor-Cuthrie. Jackson: University Press of Mississippi. 255-61.

Belsey, C. (2001). Critical Practice. London: Rutledge.

Bell, B.W. (Sept. 1992). Beloved: A Womanist Neo-Slave Narrative; or a multivocal Remembrance of Things Past. African American Review, 26(1), 7-15. 
Collins, P. H. (1990). Black Feminist Thought: Knowledge, Consciousness, and the Politics of empowerment. London: Harper Collins Academics.

Darling, M. (1994). In the Realm of Responsibility: A Conversation with Toni Morrison. Conversations with Toni Morrison. Ed. Fanille Taylor-Guthrie. Jackson: University Press with Mississippi. 246-54.

Demetrakopoulos, S. A. (Spring 1992). Maternal Bonds as a Devourers of Women's individuation in Toni Morrison Beloved. African American Review, 26(1), 51-59.

Fromm, E. (1974). The Art of Loving. New York: Harper \& Row.

Grewell, G. (1994). Circles of Sorrow, Lines of struggle: The novels of Toni Morrison. Baton Rouge: Louisiana State University Press.

Grewal, Gurleen. (1994). Memory and Matrix of History: The Politics of Loss and Recovery in Koy Kagawa's Obasan and Toni Morrison's Beloved. Memory and Cultural Politics: New Essays in Ethnic American Literature. Ed. Sing Amritjit, Joseph T. Skerrett, jr., and Robert E. (---). Hogan. Boston: Northern University Press. 140-74.

Kolawole, M.E. (1997). Womanism and African Consciousness. New Jersey: Africa World Press.

Lacan, J. (1977). Ecrits: A Selection. Trans. Alan Sheridan. New York: Norton.

Lacan, J. (1988). The Ego in Freud's Theory and in the Technique of Psychoanalysis: 1954-1955. Trans. Sylvana Tomaselli. New York: Norton.

Levinas, E. (2006). Humanism of the Other. Trans. Nidra Pollar. Intro. Richard A. Cohen. Urbana: University of Illinois Press.

Mobley, M.S. (1991). Folk Roots and Mythic Wings in Sarah Orne Jewett and Toni Morrison: The Cultural Function of Narrative. Baton Rouge: Louisiana University Press.

Morrison, T. (1987). Beloved. London: Vintage.

Morrison, T. (May 1989). Interview. “The Pain of Being Black,” Bonnie Angelo, Time, 120.

Schapiro, B. (Summer 1991). "The Bonds of Love and Boundaries of Self in Toni Morrison's Beloved." Contemporary Literature, 32(12), 194-210.

Zizek, S. (1989). The Sublime Object of Ideology. London: Verso Books. 